\title{
Study on Plasma Sterilization of Plant Anthracnose Pathogen in Water Mist
}

\author{
Masaru Tominaga *, Toshiyuki Tanaka ${ }^{\dagger}$, Tatsuya Sakoda \\ Norikazu Mizoguchi §, Yoshiyuki Kushima **
}

\begin{abstract}
In recent years, Miyazaki Prefecture located on the island of Kyushu in Japan promotes agricultural food industry. One of the activities is promotion of agricultural and livestock products. However, Miyazaki Prefecture is very far from large-scale consumption areas such as Tokyo and Osaka cities. To keep freshness of agricultural and livestock products during their transport is a serious problem from a viewing of putrefaction due to outbreak of blight. Apple Mango has been a very famous and representative product in Miyazaki Prefecture and it has successfully continued to make a good profit, however fruit rot disease such as plant anthracnose pathogen after harvest is serious. Therefore, a sterilization technique is strongly required. We here generated the dielectric barrier discharge plasma in water mist which might enable to sterilize the whole of target greengrocery because of its high diffusibility and carried out sterilization. Based on the results, fungicidal activity against Colletotrichum sp. was investigated.
\end{abstract}

Keywords: CT; D-value; plant anthracnose pathogen; plasma sterilization

\section{Introduction}

Agriculture is a main industry in Miyazaki Prefecture located on the island of Kyushu in Japan, and Miyazaki Prefecture progresses food industry such as food processing for preparation of fresh products for market and manufacture of prepared food products from agricultural and livestock products. However, Miyazaki Prefecture is very far apart from large-scale consumption areas such as Tokyo and Osaka cities. To keep freshness of agricultural and livestock products during their transport is a serious problem from a viewing of putrefaction due to blight outbreak.

\footnotetext{
* University of Miyazaki, Miyazaki, Japan

$\dagger$ University of Miyazaki, Miyazaki, Japan

* University of Miyazaki, Miyazaki, Japan

\& Miyazaki Agricultural Research Institute

** Miyazaki Agricultural Research Institute
} 
Incidentally, Apple Mango has been a very famous and representative product in Miyazaki Prefecture and it has successfully continued to make a good profit. However, fruit rot disease such as plant anthracnose pathogen after harvest is serious [1] [2] [3]. It is difficult to choose and select infected mangos from uninfected ones because the Mango anthracnose progress after harvesting, which is one of factors of claim and impairing the reliability [4]. On the other hand, agricultural chemicals use after post-harvest is not allowed in Japan. Therefore, a sterilization technique is strongly required instead of the agricultural chemicals. From this kind of circumstance, we have been developing a sterilization technique using activated species such as $\mathrm{OH}$ radicals and $\mathrm{H}_{2} \mathrm{O}_{2}$ generated by discharge plasmas.

$\mathrm{O}_{3}$ is generated through reactions between plasma and $\mathrm{O}_{2}$, and the plasma can also generate $\mathrm{OH}$ radicals and $\mathrm{H}_{2} \mathrm{O}_{2}$ through collisions with $\mathrm{H}_{2} \mathrm{O}$ [5] [6] [7] [8]. The oxidization of $\mathrm{OH}$ radical is about $10^{6}$ times higher than that of $\mathrm{O}_{3}$; therefore we focus on an advanced oxidation process with $\mathrm{OH}$ radicals and $\mathrm{H}_{2} \mathrm{O}_{2}$, which is probably superior to a sterilization using only $\mathrm{O}_{3}$. These activated species are produced through a reaction between $\mathrm{O}_{3}$ and $\mathrm{H}_{2} \mathrm{O}$ even without the plasma. However, the plasma can generate these species much more. Therefore, we generated the dielectric barrier plasma in water mist, which might enable to sterilize the whole of target greengrocery because of its high diffusibility.

In this study, we used Colletotrichum sp. as plant anthracnose pathogen and examined fungicidal activity against Colletotrichum sp.. We first applied only $\mathrm{O}_{3}$ gas (hereinafter referred to as "only $\mathrm{O}_{3}$ use") to Colletotrichum sp.. Next, we additionally applied water mist having a particle diameter of $200 \mathrm{~nm}$ (hereinafter referred to as "ozone mist"). Finally, the dielectric barrier discharge was generated over Colletotrichum sp. in oxygen gas contained the water mist (hereinafter referred to as "plasma mist"). Based on the sterilization results, we compared their sterilization characteristics.

\section{Experimental Setup}

A preliminary experiment to probe $\mathrm{O}_{3}$ contribution to sterilization was carried out by only $\mathrm{O}_{3}$ use. Figure 1 shows the experimental setup which consists of an ozonizer which is different from a plasma mist reactor which will be described below, a digital flow meter, an $\mathrm{O}_{3}$ monitor, a glove box $\left(0.4 \times 0.3 \times 0.4 \mathrm{~m}^{3}\right)$, a mist generator with a pump, a showerheads, and a high-frequency power source $(6.25 \mathrm{kHz})$ with a variable transformer. In this experiment, a mist generator pump didn't work. On the other hand, the pump was operated in the case of the ozone mist in Figure 1 was supplied. The $\mathrm{OH}$ radicals were obtained through the following reactions of (1) - (6).

$$
\begin{aligned}
& \mathrm{O}_{3}+\mathrm{H}_{2} \mathrm{O} \rightarrow \mathrm{HO}_{3}^{+}+\mathrm{OH}^{-} \\
& \mathrm{O}_{3}+\mathrm{OH}^{-} \rightarrow \mathrm{HO}_{2}^{-}+\mathrm{O}_{2} \\
& \mathrm{O}_{3}+\mathrm{HO}_{2}^{-} \rightarrow \mathrm{O}_{3}^{-}+\mathrm{HO}_{2} \\
& \mathrm{HO}_{3} \rightarrow \mathrm{OH}+\mathrm{O}_{2} \\
& \mathrm{HO}_{3}^{+}+\mathrm{OH}^{-} \rightarrow 2 \mathrm{OH}_{2} \\
& \mathrm{O}_{3}+\mathrm{HO}_{2} \rightarrow \mathrm{OH}+2 \mathrm{O}_{2}
\end{aligned}
$$


A surface discharge type ozonizer was arranged at the outside of a glove box, i.e., $\mathrm{O}_{3}$ generated at the outside of the glove box was supplied from outlet of a shower head with a diameter of about $50 \mathrm{~mm}$. The $\mathrm{O}_{3}$ concentration was measured by an $\mathrm{O}_{3}$ monitor before introducing $\mathrm{O}_{3}$ to the glove box and was set at $5 \mathrm{ppm}$ or $10 \mathrm{ppm}$, which was controlled by varying applied voltage to the ozonizer. The flow rate was kept at $3.5 \mathrm{~L} / \mathrm{min}$.

Cultivated pathogen of plant anthracnose for sterilization examinations is shown in Figure 2. The pathogen of the plant anthracnose was cultivated on Potato Dextrose Agar (PDA) medium for 14 days. A spore of anthracnose which was anticipated to be included in the medium was not apparent as shown in Figure 2(b) because the size of a spore is in the range of about $4-6 \mu \mathrm{m} \times 12$ $-14 \mu \mathrm{m}$. The cultivated pathogen on the medium was picked up at any 3 areas from a laboratory dish with $10 \mathrm{~mm}$ in diameter. After stirring in hyperpure water, $100 \mu \mathrm{l}$ of the stirring water was pipetted and coated on another PDA medium. The distance between the PDA medium and the $\mathrm{O}_{3}$ outlet of the shower head was about $16 \mathrm{~mm}$. After the sterilization, we counted the number of colonies on the medium cultivated for $48 \mathrm{~h}$ in an incubator.

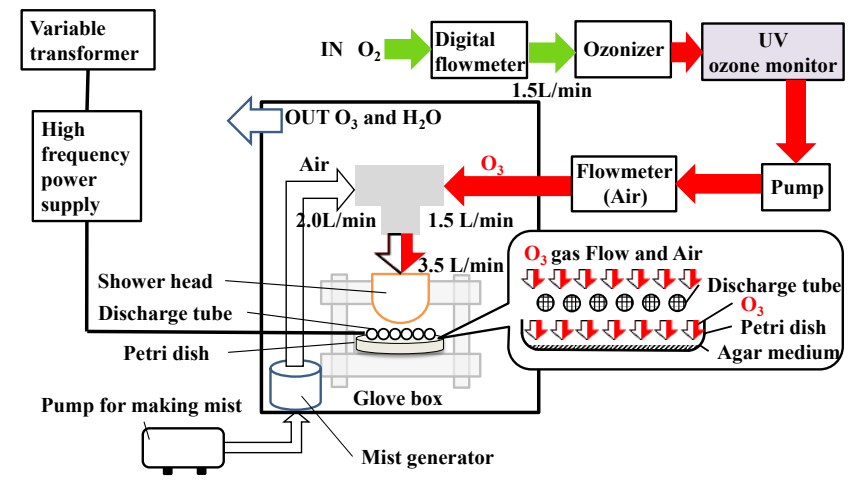

Figure 1: Schematic diagram of experiment setup for only $\mathrm{O}_{3}$ use

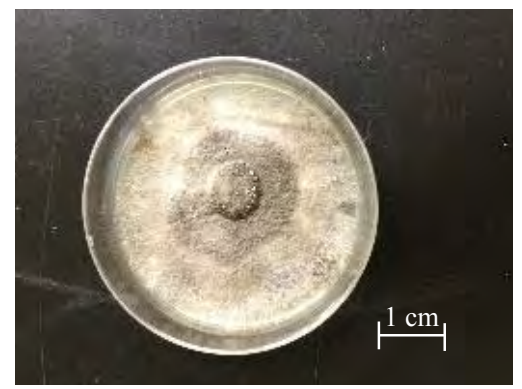

(a) Appearance of medium

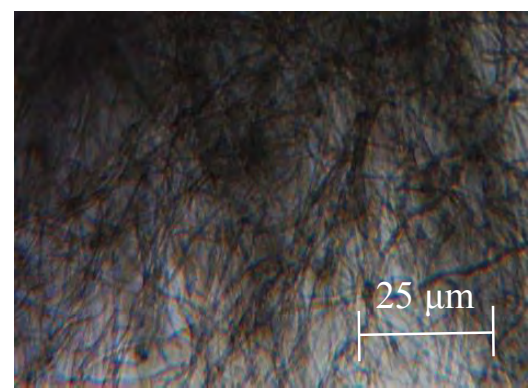

(b) Enlarged view

Figure 2: Appearance of pathogen of plant anthracnose

Figure 3 shows the experiment setup in the case where sterilization was carried out by using the dielectric barrier discharge operated in oxygen gas containing water mist. Here, a mist generator was operated, and oxygen gas containing water mist with a particle diameter of about $200 \mathrm{~nm}$ was discharged. Temperature and relative humidity in a glove box $\left(0.4 \times 0.3 \times 0.4 \mathrm{~m}^{3}\right)$ was meas-ured by a thermohygrometer, and then the absolute humidity was calculated. The dielectric bar-rier discharge tubes were arranged in 6 rows, and the distance between PDA medium and the discharge tubes were about $12 \mathrm{~mm}$. Each discharge tube with a length of $100 \mathrm{~mm}$ was composed 
of a copper wire with a diameter of $0.3 \mathrm{~mm}$ wound around a glass tube with a diameter of $3 \mathrm{~mm}$. The installation interval of the 6 rows was about $5 \mathrm{~mm}$. The inside of the glass tube were filled with copper powder, to which high voltage was applied. The operating gas with a flow rate of 3.5 $\mathrm{L} / \mathrm{min}$ was oxygen supplied from a shower head arranged at $16 \mathrm{~mm}$ upper part from a PDA medium. Thus, the discharge was produced in oxygen containing water mist. The exhaust $\mathrm{O}_{3}$ concentration from the glove box was measured by an $\mathrm{O}_{3}$ monitor.

In this case, not only $\mathrm{O}_{3}$ but also radicals such as $\mathrm{O}$ and $\mathrm{OH}$ may be produced. The $\mathrm{OH}$ radicals were obtained through the following reactions of (7) - (9). It is said that oxidation power of $\mathrm{OH}$ is higher than that of $\mathrm{O}_{3}$ and that sterilization power is much higher than that of $\mathrm{O}_{3}$. Additionally, unstable $\mathrm{H}_{2} \mathrm{O}_{2}$ formed through reaction (9) reacts with another species, and then radicals such as $\mathrm{OH}$ and $\mathrm{HO}_{2}$ are formed. Therefore, effective sterilization is expected when the dielectric barrier discharge is produced in oxygen containing water mist. Phots of treatment area and dielectric barrier discharge are shown in Figure 4.

$$
\begin{aligned}
& \mathrm{H}_{2} \mathrm{O}+\mathrm{e}(>6.4 \mathrm{eV}) \rightarrow \mathrm{H}+\mathrm{OH}+\mathrm{e} \\
& \mathrm{O}+\mathrm{H}_{2} \mathrm{O} \rightarrow \mathrm{OH}+\mathrm{OH} \\
& \mathrm{OH}+\mathrm{OH} \rightarrow \mathrm{H}_{2} \mathrm{O}_{2} \\
& \mathrm{O}+\mathrm{H}_{2} \mathrm{O}_{2} \rightarrow \mathrm{OH}+\mathrm{HO}_{2} \\
& \mathrm{H}_{2} \mathrm{O}_{2}+\mathrm{OH} \rightarrow \mathrm{H}_{2} \mathrm{O}+\mathrm{HO}_{2} \\
& \mathrm{H}_{2} \mathrm{O}_{2}+\mathrm{HO}_{2} \rightarrow \mathrm{H}_{2} \mathrm{O}+\mathrm{O}_{2}+\mathrm{OH}
\end{aligned}
$$

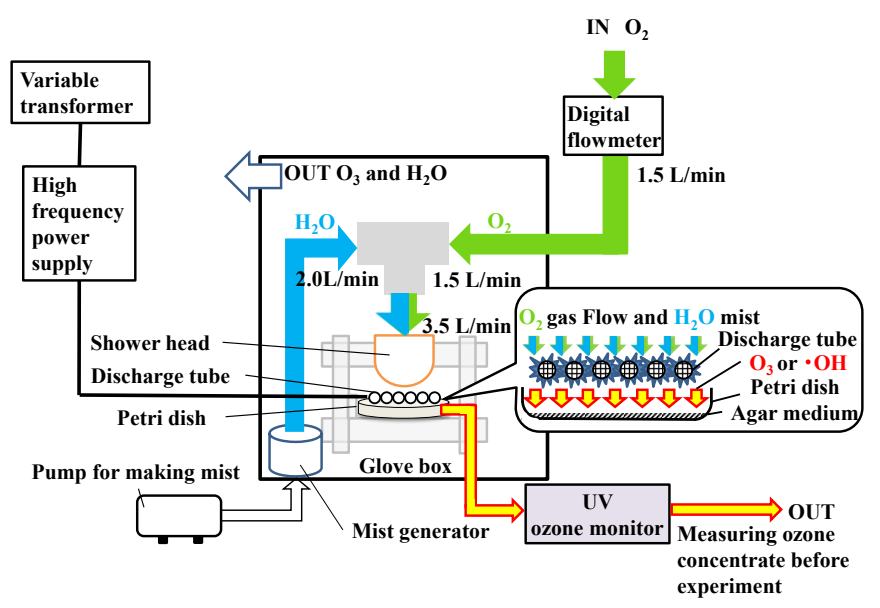

Figure 3: Schematic diagram of experimental setup for the plasma mist having a particle diameter of $200 \mathrm{~nm}$

We executed sterilizations in which $\mathrm{CT}$ (product of $\mathrm{O}_{3}$ concentration and sterilization time) was varied until $40 \mathrm{ppm} \cdot \mathrm{min}$ at intervals of $4 \mathrm{ppm} \cdot \mathrm{min}$. It is possible to compare sterilization effect related to $\mathrm{O}_{3}$ and radicals because $\mathrm{CT}$ value represents the absolute amount of $\mathrm{O}_{3}$. After sterilization experiment, we counted the number of colonies on the medium cultivated for $48 \mathrm{~h}$ in an incubator. We carried out 2-times experiments for each experimental condi-tion. 


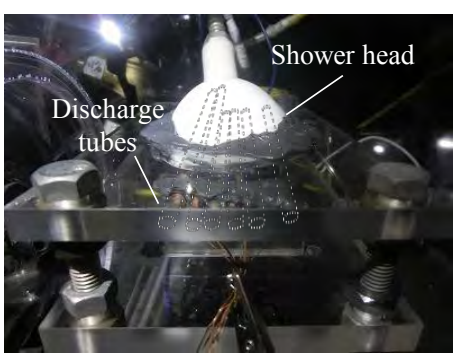

(a) Appearance of discharge area

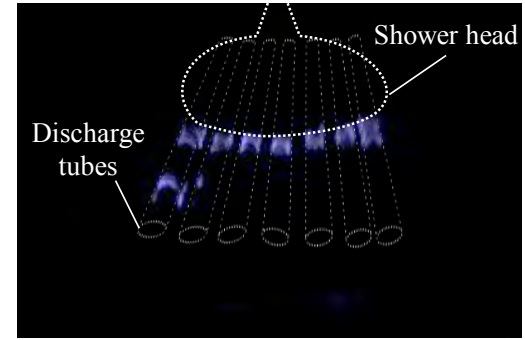

(b) Photo of dielectric barrier discharge

Figure 4: Phots of treatment area and dielectric barrier discharge

\section{Results and Discussions}

Table 1 shows the averaged number of colonies in the case of only $\mathrm{O}_{3}$ use and ozone mist. CT dependence of colony survival rate for sterilization of pathogen of plant anthracnose for only $\mathrm{O}_{3}$ use and ozone mist are shown in Figures 5 and 6, respectively. Additionally, Tables 2 and 3 show approximation for only $\mathrm{O}_{3}$ use and ozone mist, and those experimental conditions of temperature, relative humidity, absolute humidity, and $\mathrm{O}_{3}$ concentration. As shown in Table 3, the absolute humidity for two experiments were the almost same in the case of only $\mathrm{O}_{3}$ use. On the other hand, the absolute humidity for the case of ozone mist became higher because a mist generator operated here although those for two experiments were the almost same. The horizontal axis is CT value while the vertical axis is the logarithmic function on colony survival rate. We evaluated sterilization effect using $\mathrm{D}$-value which is time to reduce the number of colonies to one - tenth of that of preprocessing colonies. Therefore, the smaller the D-value, the higher the sterilization effect becomes.

Circles in Figures 5 and 6 denote results obtained for only $\mathrm{O}_{3}$ use with concentration of 5 ppm. The applied voltage to generate $\mathrm{O}_{3}$ of $5 \mathrm{ppm}$ was $1.82 \mathrm{kV}$. Circles denote ones obtained for only $\mathrm{O}_{3}$ use with concentration of $10 \mathrm{ppm}$. In this case, the applied voltage was $1.85 \mathrm{kV}$. These colony survival rate was anticipated to decrease exponentially from CT $=0 \mathrm{ppm} \cdot \mathrm{min}$. However, there was a period of time during which sterilization didn't advance until a certain CT (hereinafter referred to as "induction period"). Such CT exists at around $16 \mathrm{ppm} \cdot \mathrm{min}$ in Figures 5 and 6 . The induction period is probably due to the septal wall of mycelia Colletotrichum sp. which has tol-erant against $\mathrm{O}_{3}$. To approximate accurately, an approximately line was drawn exponentially as shown in Table 2 in which CT-value shown as " $x$ ", which referred colony survival rate after induction period. From these approximately lines, D-values in the cases of $5 \mathrm{ppm}$ and $10 \mathrm{ppm}$ for only $\mathrm{O}_{3}$ use are $41 \mathrm{ppm} \cdot \mathrm{min}$ and $26 \mathrm{ppm} \cdot \mathrm{min}$, respectively. Similarly, D-values in the cases of $5 \mathrm{ppm}$ and $10 \mathrm{ppm}$ for ozone mist are $48 \mathrm{ppm} \cdot \mathrm{min}$ and $29 \mathrm{ppm} \cdot \mathrm{min}$, respectively. Thus, the sterilization effect at $10 \mathrm{ppm}$ was higher. This sterilization effect is due to the large amount of $\mathrm{O}_{3}$ per unit time. 
Table 1: Number of colony for only $\mathrm{O}_{3}$ use and ozone mist

\begin{tabular}{ccccc}
\hline $\begin{array}{c}\text { CT value } \\
{[\mathrm{ppm} \cdot \mathrm{min}]}\end{array}$ & $5 \mathrm{ppm}$ & $10 \mathrm{ppm}$ & $5 \mathrm{ppm}$ & $10 \mathrm{ppm}$ \\
\hline \hline 0 & 308 & 67 & 308 & 78 \\
4 & 351 & 62 & 335 & 82 \\
8 & 323 & 53 & 307 & 64 \\
12 & 307 & 51 & 353 & 64 \\
16 & 346 & 44 & 287 & 46 \\
20 & 259 & 19 & 137 & 17 \\
24 & 202 & 12 & 172 & 24 \\
28 & 85 & 6 & 167 & 4 \\
32 & 42 & 3 & 84 & 3 \\
36 & 48 & 1 & 0 & 2 \\
40 & 44 & 1 & 47 & 10 \\
\hline
\end{tabular}

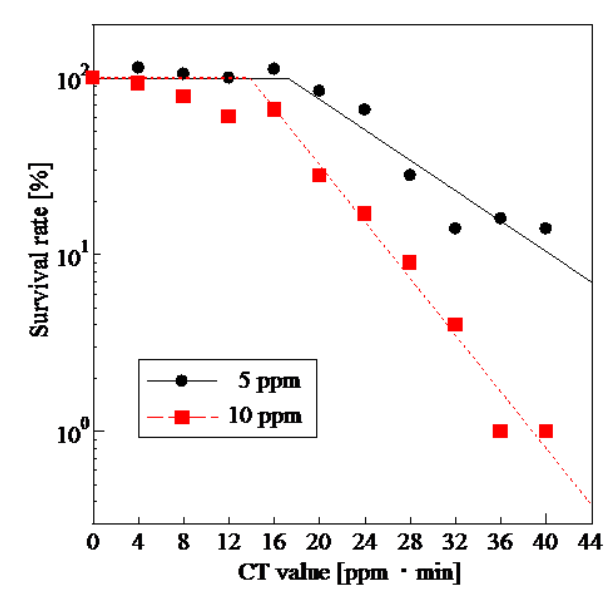

Figure 5: CT dependence of colony survival rate for sterilization for only $\mathrm{O}_{3}$ use

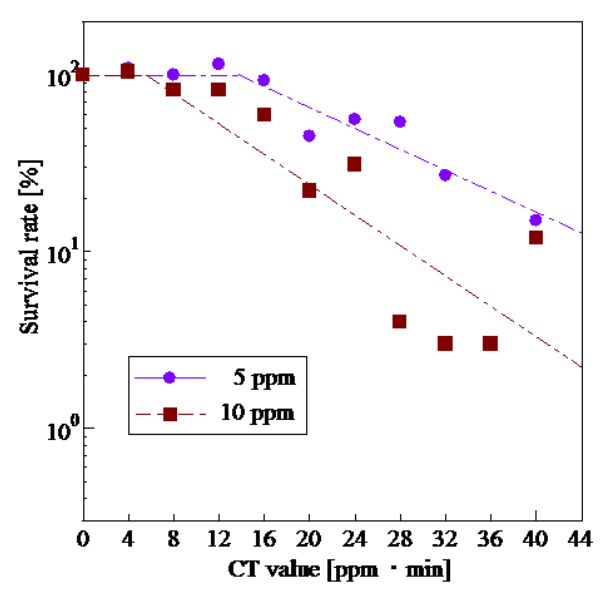

Figure 6: CT dependence of colony survival rate for sterilization for ozone mist

Table 2: Approximation for only $\mathrm{O}_{3}$ use and ozone mist

\begin{tabular}{ccc}
$\begin{array}{c}\text { Processing } \\
\text { method }\end{array}$ & 5 ppm & 10 ppm \\
\hline Only $\mathrm{O}_{3}$ use & $\mathrm{e}^{(-0.10) x+6.3}$ & $\mathrm{e}^{(-0.18) x+7.2}$ \\
Ozone mist & $\mathrm{e}^{(-0.07) x+5.5}$ & $\mathrm{e}^{(-0.10) x+5.2}$
\end{tabular}


Table 3: Experimental conditions for only $\mathrm{O}_{3}$ use and ozone mist

\begin{tabular}{ccccc}
\hline $\begin{array}{c}\text { Processing } \\
\text { method }\end{array}$ & $\mathrm{O}_{3}[\mathrm{ppm}]$ & Temperature $\left[{ }^{\circ} \mathrm{C}\right]$ & $\begin{array}{c}\text { Relative } \\
\text { Humidity [\%] }\end{array}$ & $\begin{array}{c}\text { Absolute } \\
\text { Humidity } \\
{\left[\mathrm{g} / \mathrm{m}^{3}\right]}\end{array}$ \\
\hline \multirow{2}{*}{ Only $\mathrm{O}_{3}$ use } & 5 & 14.8 & 30 & 3.8 \\
& 10 & 14.1 & 26 & 3.1 \\
Ozone mist & 5 & 15.2 & 60 & 6.4 \\
\hline
\end{tabular}

Table 4 shows the number of colonies in the case of the plasma mist. Figure 7 shows CT dependence of colony survival rate for sterilization of pathogen of plant anthracnose in which the dielectric barrier discharge was produced in oxygen containing water mist. In addition, Table 5 shows the experimental conditions. The absolute humidity for two experiments is high as those for experiments using ozone mist because a mist generator also operated here. Circles in Figure 7 denote results obtained by the plasma mist with exhaust $\mathrm{O}_{3}$ concentration of $5 \mathrm{ppm}$. In this case, the applied voltage was $1.64 \mathrm{kV}$. Square denote ones obtained by plasma mist with exhaust $\mathrm{O}_{3}$ concentration of $10 \mathrm{ppm}$. In this case, the applied voltage was $1.76 \mathrm{kV}$. Any induction period, as shown in Figures 5 and 6, were not recognized for two cases. Thus, approximation for $5 \mathrm{ppm}$ and $10 \mathrm{ppm}$ were drawn exponentially as $\mathrm{e}^{-0.05 x+4.6}$ and $\mathrm{e}^{-0.11 x+4.6}$, in which a survival rate at $100 \%$ is matched with $\mathrm{CT}=0 \mathrm{ppm} \cdot \mathrm{min}$. From these approximately lines, D-values in the cases of $5 \mathrm{ppm}$ and $10 \mathrm{ppm}$ of $\mathrm{O}_{3}$ in Figure 7 are $45 \mathrm{ppm} \cdot \mathrm{min}$ and $20 \mathrm{ppm} \cdot \mathrm{min}$, respectively. As in the case of only $\mathrm{O}_{3}$ use, the sterilization effect for $\mathrm{O}_{3}$ concentration of $10 \mathrm{ppm}$ is higher. Here, as mentioned above, it should be noted that there is no induction period. Active species such as $\mathrm{O}, \mathrm{OH}, \mathrm{H}_{2} \mathrm{O}$ and so on probably destructs septal wall of mycelia of Colletotrichum sp..

In addition, to confirm superiority of the plasma mist, we compared the sterilizations obtained by the plasma mist, only $\mathrm{O}_{3}$ use and ozone mist. The comparison results by three processing methods at $\mathrm{O}_{3}$ concentration of $5 \mathrm{ppm}$ is shown in Figure 8. Table 6 summary of D-values at $\mathrm{O}_{3}$ concentration of $5 \mathrm{ppm}$ and $10 \mathrm{ppm}$. From Figure 8 and Table 6 , the different sterilization effect among only $\mathrm{O}_{3}$ use, ozone mist and plasma mist was not apparent at 5 ppm. Figure 9 shows the comparison result by three processing methods at $\mathrm{O}_{3}$ concentration of $10 \mathrm{ppm}$. From Figures 8 and 9 , active species such as $\mathrm{O}, \mathrm{OH}, \mathrm{H}_{2} \mathrm{O}_{2}$ are not probably generated as they could contribute the sterilization because the $\mathrm{D}$-values of the ozone mist for $5 \mathrm{ppm}$ and $10 \mathrm{ppm}$ are the almost same as that of only $\mathrm{O}_{3}$ use. The sterilization of the plasma mist is more effective than those of only $\mathrm{O}_{3}$ use and ozone mist. D-value, shown in Table 6, of the plasma mist is about 0.71 times smaller than that of only $\mathrm{O}_{3}$ use. Additionally, the plasma mist also is about 0.69 times smaller than the ozone mist.

Thus, in a high humid environment produced by water mist having a particle diameter of $200 \mathrm{~nm}$, not only $\mathrm{O}_{3}$ but also active species such as $\mathrm{O}, \mathrm{OH}, \mathrm{H}_{2} \mathrm{O}$ and so on are produced by applying relatively high voltage to generate the dielectric barrier discharge. That is, the increase of applied voltage promote the increases of $\mathrm{O}_{3}$ and active species formed through reactions between $\mathrm{H}_{2} \mathrm{O}$ and $\mathrm{O}_{3}$. When the applied voltage was set to generate $\mathrm{O}_{3}$ with concentration of 10 ppm, not only $\mathrm{O}_{3}$ but also active species such as $\mathrm{O}, \mathrm{OH}, \mathrm{H}_{2} \mathrm{O}$ and so on were produced and they contributed to sterilization effectively. In contrast, the amount of active species was less when $\mathrm{O}_{3}$ concentration 
was $5 \mathrm{ppm}$. The produced active species probably destructed septal wall of mycelia of Colletotrichum sp.; therefore, the survival rate began to decrease from $\mathrm{CT}=0 \mathrm{ppm} \cdot \mathrm{min}$. However, obvious superiority was not seen in comparison with other two processing methods.

Table 4: The number of colonies for plasma mist

\begin{tabular}{ccc}
$\begin{array}{c}\text { CT value } \\
\text { ppm } \cdot \mathrm{min}]\end{array}$ & $5 \mathrm{ppm}$ & $10 \mathrm{ppm}$ \\
\hline \hline 0 & 251 & 65 \\
4 & 247 & 80 \\
8 & 207 & 39 \\
12 & 131 & 25 \\
16 & 198 & 20 \\
20 & 114 & 5 \\
24 & 112 & 0 \\
28 & 19 & 1 \\
32 & 62 & 1 \\
36 & 64 & 0 \\
40 & 17 & 3 \\
\hline
\end{tabular}

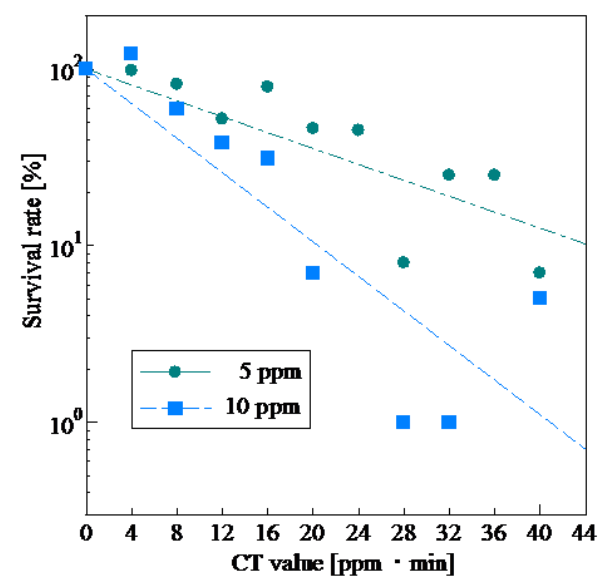

Figure 7: CT dependence of colony survival rate for sterilization in the case of the plasma mist Table 5: Temperature, humidity and absolute humidity in the case of plasma mist

\begin{tabular}{cccc}
$\mathrm{O}_{3}[\mathrm{ppm}]$ & Temperature $\left[{ }^{\circ} \mathrm{C}\right]$ & $\begin{array}{c}\text { Relative } \\
\text { Humidity }[\%]\end{array}$ & $\begin{array}{c}\text { Absolute } \\
\text { Humidity }\left[\mathrm{g} / \mathrm{m}^{3}\right]\end{array}$ \\
\hline \hline 5 & 15.4 & 48 & 6.3 \\
10 & 14.6 & 48 & 6.0 \\
\hline
\end{tabular}




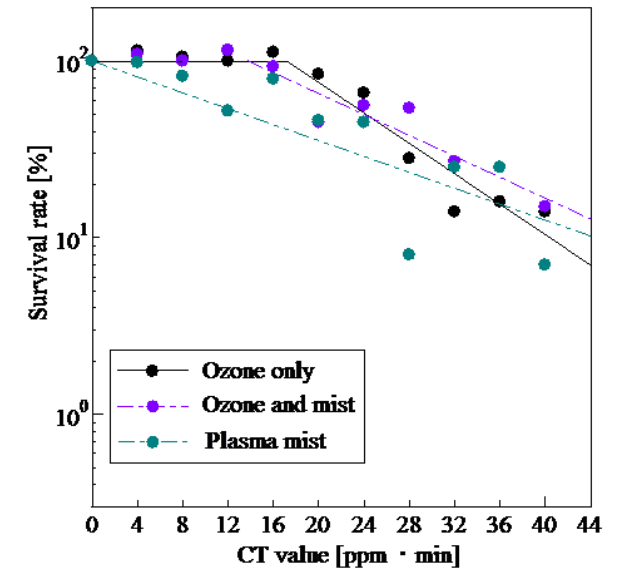

Figure 8: Comparison of sterilization

between the only $\mathrm{O}_{3}$ use, ozone mist and the plasma mist for $\mathrm{O}_{3}$ concentration of 5 ppm

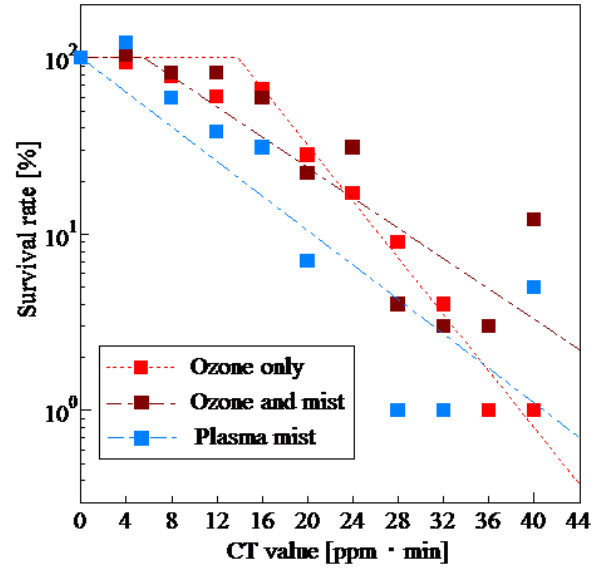

Figure 9: Comparison of sterilization between the only $\mathrm{O}_{3}$ use, ozone mist and the plasma mist for $\mathrm{O}_{3}$ concentration of $10 \mathrm{ppm}$

Table 6: Comparison of D-values between three methods

\begin{tabular}{cccc}
\hline $\mathrm{O}_{3}[\mathrm{ppm}]$ & $\begin{array}{c}\text { The only } \mathrm{O}_{3} \text { use } \\
{[\mathrm{ppm} \cdot \mathrm{min}]}\end{array}$ & $\begin{array}{c}\text { The ozone mist } \\
{[\mathrm{ppm} \cdot \mathrm{min}]}\end{array}$ & $\begin{array}{c}\text { The Plasma mist } \\
{[\mathrm{ppm} \cdot \mathrm{min}]}\end{array}$ \\
\hline \hline 5 & 41 & 48 & 45 \\
10 & 28 & 29 & 20 \\
\hline
\end{tabular}

\section{Conclusion}

To reduce fruit rot disease of Apple mango which is very famous and representative product in Miyazaki Prefecture, we examined to sterilize plant anthracnose pathogen by using $\mathrm{O}_{3}$ or active species formed by the dielectric barrier discharge in oxygen gas containing water mist having a particle diameter of about $200 \mathrm{~nm}$. Here, we used Colletotrichum sp. as plant anthracnose pathogen.

As a preliminary experiment to probe the contribution of $\mathrm{O}_{3}$ to sterilization, only $\mathrm{O}_{3}$ gas generated at the outside of a processing chamber was applied. $\mathrm{O}_{3}$ with $10 \mathrm{ppm}$ was more effective to the sterilization than that with $5 \mathrm{ppm}$, and a large amount of $\mathrm{O}_{3}$ per unit time contributed to the sterilization of Colletotrichum sp.. Additionally, for only $\mathrm{O}_{3}$ use, the induction period during which sterilization didn't advance until a certain $\mathrm{CT}$ existed. The induction period is probably due to the septal wall of mycelia Colletotrichum sp. which has tolerant against $\mathrm{O}_{3}$. In the case of the ozone mist, the similar trend to only $\mathrm{O}_{3}$ use was apparent. The sterilization effect by the ozone mist with $\mathrm{O}_{3}$ with $5 \mathrm{ppm}$ and $10 \mathrm{ppm}$ was the almost same as that of only $\mathrm{O}_{3}$ use. Therefore, active species such as $\mathrm{OH}$ radicals and $\mathrm{H}_{2} \mathrm{O}_{2}$ and so on were not generated enough to contribute the sterilization. 
Incidentally, any induction period was not recognized for sterilization by using the plasma mist. When the dielectric barrier discharge is produced in oxygen containing water mist, not only $\mathrm{O}_{3}$ but also $\mathrm{OH}$ radical may be produced through reactions between $\mathrm{H}_{2} \mathrm{O}$, electron and $\mathrm{O}$. Furthermore, radicals such as $\mathrm{OH}$ and $\mathrm{HO}_{2}$ are formed through between unstable $\mathrm{H}_{2} \mathrm{O}_{2}$ and another species. Therefore, effective sterilization is expected when the dielectric barrier discharge is produced in oxygen containing water mist. Septal wall of mycelia might be destructed by the active species. The superiority of the plasma mist could be confirmed when exhaust $\mathrm{O}_{3}$ concentration was $10 \mathrm{ppm}$. Thus, not only $\mathrm{O}_{3}$ but also active species such as $\mathrm{O}, \mathrm{OH}$, $\mathrm{H}_{2} \mathrm{O}$ and so on are produced and they contributed to sterilization effectively when the applied voltage was set to generate $\mathrm{O}_{3}$ with concentration of $10 \mathrm{ppm}$ in a high humid environment.

\section{Reference}

\subsubsection{Article in a journal or magazine}

[1] P. Ulises Bautista-Rosales, M. Calderon-Santoyo, R. Servín-Villegas, N. Ang-elica Ochoa-Alvarez, R. Vazquez-Juarez, J. Arturo Ragazzo-S_anchez, "Biocontrol action mechanisms of Cryptococcus laurentii on Colletotrichum gloeosporioides of mango", Crop Protection Vol.65, pp.194-201, 2014

[2] P. Ulises Bautista-Rosales, M. Calderon-Santoyo, R. Servín-Villegas, N. Ang-elica Ochoa-Alvarez, R. Vazquez-Juarez, J. Arturo Ragazzo-S_anchez, "Action mechanisms of the yeast Meyerozyma caribbica for the control of the phytopathogen Colletotrichum gloeosporioides in mangoes", Vol.65, pp.193-301, 2013

[3] Yonas Kefialew, Amare Ayalew, "Postharvest biological control of anthracnose (Colletotrichum gloeosporioides) on mango (Mangifera indica)", Postharvest Biology and Technology Vol.50 pp.8-11, 2008

[4] T. Sato and J. Moriwaki, "Causal fungi of plant anthracnose (1)", Japan society for microbial resources and systematics pp.27-32 [In Japanese]

[5] D. Gumuchian, S. Cavadias, X. Duten, M. Tatoulian, P. Da Costa, and S. Ognier, "Organic pollutants oxidation by needle/plate plasma discharge:on the influence of the gas nature", Chemical Engineering and Processing, Vol.82, pp.185-192, 2014

[6] S. Kitazaki, A. Tanaka, and N. Hayashi, "Sterilization of narrow tube inner surface using discharge plasma, ozone, and UV light irradiation”, Vacuum Vol.110 pp.217-220, 2014

[7] T. Itarashiki, N. Hayashi, and A. Yonesu "Sterilization effect of nitrogen oxide radicals generated by microwave plasma using air", Vacuum Vol.110 pp.213-216, 2014

[8] R. Ben Gadri, J. Reece Roth, T. C. Montie, K. Kelly-Wintenberg, P. P.-Y. Tsai, D. J. Helfritch, P. Feldman, Daniel M. Sherman, F. Karakaya, Z. Chen, and UTK Plasma Sterilization Team, "Sterilization and plasma processing of room temperature surfaces with a one atmosphere uniform glow discharge plasma (OAUGDP)", Surface and Coatings Technology Vol.131, pp.528-542, 2000 